\title{
Methane Potential of Waste Activated Sludge and Fatty Residues: Impact of Codigestion and Alkaline Pretreatments
}

\author{
Hélène Carrère $^{\mathrm{a}, *}$, Yan Rafrafi ${ }^{\mathrm{a}}$, Audrey Battimelli ${ }^{\mathrm{a}}$, Michel Torrijos ${ }^{\mathrm{a}}$, Jean-Philippe Delgenès ${ }^{\mathrm{a}}$ and \\ Gilles Ruysschaert \\ ${ }^{a}$ INRA, UR50, Laboratoire de Biotechnologie de l'Environnement, Avenue des Etangs, F-11100 Narbonne, France \\ ${ }^{b}$ Lille Métropole Communauté Urbaine, 1, rue du Ballon, 59034 Lille Cedex, France
}

\begin{abstract}
The aim of this study was to maximise methane production from waste activated sludge (WAS) originating from extended aeration process and presenting a low methane potential $\left(190 \mathrm{~mL} \mathrm{CH}_{4} \cdot \mathrm{g}^{-1} \mathrm{OM}\right)$. WAS co-digestion with fatty residues ( $\mathrm{FR}, 560 \mathrm{~mL} \mathrm{CH} \cdot \mathrm{g}^{-1} \mathrm{OM}$ ) produced during pretreatments of the effluents from wastewater treatment plants in the Lille area and fatty wastewaters ( $\mathrm{FW}$, around $700 \mathrm{~mL} \mathrm{CH}_{4} \cdot \mathrm{g}^{-1} \mathrm{OM}$ ) collected from restaurants was assessed by batch experiments. Moreover saponification/alkali pretreatments improved kinetics of anaerobic digestion but had a low impact on methane potential (+ 6-7\%) of the mixed waste composed of $66.6 \%$ of FW, 33.3\% of WAS and $0.1 \%$ of FR. As results did not depend on $\mathrm{pH}$ ranging from 8 to 10 (addition of 0.12 to $0.21 \mathrm{~g}_{\mathrm{KOH}} \mathrm{g}_{\mathrm{OM}}{ }^{-1}$ ) nor temperature ranging from 80 to $120^{\circ} \mathrm{C}$, the least severe studied pretreatment conditions $\left(80^{\circ} \mathrm{C}\right.$ and $\left.\mathrm{pH}=8\right)$ may be selected for further studies on continuous anaerobic reactors.
\end{abstract}

Keywords: Anaerobic digestion, batch, biogas, biomethane, saponification, alkali pretreatment.

\section{INTRODUCTION}

Wastewater treatment plants have to ensure efficient removal of carbon, phosphorous and nitrogen pollutants. If phosphorous treatment is carried out, either by biological or physico-chemical processes, activated sludge processes are widely used to remove carbon and nitrogen pollutants. Conventional microbial nitrogen removal is based on aerobic autotrophic nitrification (i.e., the conversion of $\mathrm{NH}_{4}{ }^{+}$to $\mathrm{NO}_{2}{ }^{-}$ and further to $\mathrm{NO}_{3}{ }^{-}$) and anoxic heterotrophic denitrification (i.e., the conversion of $\mathrm{NO}_{3}{ }^{-}$to gaseous nitrogen). This conventional biological nitrogen removal proceeds slowly due to slow autotrophic microorganisms growth and their low activity and yield [1]. High biomass retention time has thus to be maintained in the system to avoid washout. Retention time of conventional suspended activated sludge processes are thus usually around 20 days. These processes are also called extended aeration processes. Moreover the denitrification step needs electron donors, such as methanol, acetate, ethanol, lactate and glucose which makes full-scale denitrification expensive [2]. An alternative to the addition of these organic compounds may be the use of suspended matter present in wastewaters: primary settlers are thus not present in wastewater treatment plants and no primary sludge are produced.

On the other hand, sewage sludge anaerobic digestion is gaining more and more interest due to its multiple advantages: i) the reduction of the amount of residual sludge, ii) the production of renewable energy (biomethane) which may be valorised as heat and/or electricity or biofuel, and iii) the production of an organic digestate rich in $\mathrm{N}$ and $\mathrm{P}$ nutriments

*Address correspondence to this author at INRA, Laboratoire de Biotechnologie de l'Environnement, Avenue des Etangs, 11100 Narbonne France; Tel: +33 468425 168; Fax: +33 468425 160; E-mail: carrere@supagro.inra.fr which may be valorised by land application. Moreover, primary sludge are known to lead to higher biomethane production than waste activated sludge. Indeed, Kepp and Solheim [3] indicated methane productions of 300 to $350 \mathrm{~L} \mathrm{CH}_{4}$ per $\mathrm{kg}$ of feed organic matter (OMfeed) for primary sludge, 260 to $290 \mathrm{~L} \mathrm{CH}_{4} \mathrm{~kg}^{-1}$ OMfeed for mixed sludge and 140 to $210 \mathrm{~L}$ $\mathrm{CH}_{4} \mathrm{~kg}^{-1} \mathrm{OM}_{\text {feed }}$ for secondary or waste activated sludge (WAS). Among WAS, sludge originating from extended aeration processes have been reported to be less biodegradable than sludge originating from high load activated sludge process [4].

Waste activated sludge (WAS) resulting from wastewater treatment plants treating carbon and nitrogen pollution by extended aeration processes thus present low methane potentials. Lots of studies have considered various pretreatments to improve the conversion of sewage sludge to biogas [5-7]. These pretreatments may be classified into thermal, biological, chemical or mechanical treatments. Chemical treatments consist of oxidation or alkali treatments and may be combined or not with thermal treatments. Mechanical treatments are mainly ultrasounds, high pressure treatments and grinding. Among all of them, thermal and ultrasonic treatments are the most applied, specially at full scale plants [8-10].

Another option to increase biogas production from a WAS digester is co-digestion with residues which present high methane potential such as fatty wastes [11,12]. However, too high lipid content (38-71\% of organic matter) in the feed mixture resulted in incomplete degradation, in accumulation of volatile fatty acids in the digester, and subsequent decrease in biogas production. This was explained by methanogenesis step inhibition by long chain fatty acids [11]. Beside, anaerobic digestion of fatty wastes may be enhanced by different preteatments such as acid treatment (ad- 
Table 1. Composition of Waste Activated Sludge (WAS), Fatty Residues (FR) and Fatty Wastewaters (FW)

\begin{tabular}{|c|c|c|c|c|}
\hline & COD $\left(\mathrm{g} \mathrm{L}^{-1}\right)$ & DM $\left(\mathrm{g} \mathrm{kg}^{-1}\right)$ & OM $\left(\mathrm{g} \mathrm{kg}^{-1}\right)$ & HEM $\left(\mathrm{g} \mathrm{L}^{-1}\right)$ \\
\hline \hline WAS & 37.9 & 43.69 & 22.45 & 1.46 \\
\hline FR & 85.6 & 72.17 & 60.94 & 40.20 \\
\hline FW & 92.3 & 42.66 & 32.73 & 21.49 \\
\hline
\end{tabular}

COD : Chemical Oxygen Demand, DM: Dry Matter, OM: Organic Matter, HEM: Heptane Extractable Matter.

dition of $\mathrm{HCl}$ till $\mathrm{pH}=2-2.5$ [13]) or saponification. Saponification has been carried out with different experimental conditions : at $80^{\circ} \mathrm{C}$ with $\mathrm{KOH}$ in excess [14], at $80^{\circ} \mathrm{C}$ with $\mathrm{KOH}$ until $\mathrm{pH}=9[15]$ or at $60^{\circ} \mathrm{C}$ with $\mathrm{NaOH} 0.3$ wt. \% [16, 17]. However, an alkali treatment at room temperature $\left(\mathrm{NaOH}, 2-16 \mathrm{~g} \mathrm{~L}^{-1}\right)$ did not lead to a significant solubilisation of slaughterhouse wastes containing approximately $3 \mathrm{~g} \mathrm{~L}^{-1}$ of pork fat particles [18]. Finally, whereas thermal hydrolysis at $160-180^{\circ} \mathrm{C}$ is efficient to increase biogas production from waste activated sludge [19], thermal treatments of some fatty wastes at $60-70^{\circ} \mathrm{C}[13]$ or at $133^{\circ} \mathrm{C}$ with a pressure higher than 3 bar [20] led to the formation of recalcitrant compounds which had a negative impact on subsequent anaerobic digestion.

The objective of this paper was to assess the possibility of maximising methane production from waste activated sludge by codigestion with fatty residues (FR) produced during pretreatments of the urban effluents from wastewater treatment plants in the Lille area and fatty wastewaters (FW) collected from restaurants. Moreover, the impact of saponification/alkaline hydrolysis at 80 and $120^{\circ} \mathrm{C}$ on the mesophilic batch anaerobic digestion of the mixed residue was investigated.

\section{MATERIAL AND METHODOLOGY}

\subsection{Sludge and Fatty Residues}

Waste activated sludge was collected in Wattrelos wastewater treatment plant after its thickening by flotation. The average sludge retention time in the extended aeration process (sludge age) was 21 days. Fatty residues (FR) were collected from the pretreatment of urban wastewater in Neuville and Wattrelos plants. They were sieved with a $1 \mathrm{~cm}$ grid and were mixed in the weight ratio 62/38 (Neuville/Wattrelos). Fatty wastewaters (FW) were collected at their discharging by a truck at the wastewater treatment plant. They were collected from several restaurants and were composed of grease tanks washing waters. The composition of the 3 wastes is given in Table $\mathbf{1}$.

\subsection{Anaerobic Digestion}

Methane production was assessed by batch biochemical methane potential (BMP) tests in mesophilic conditions. Each sample was mixed in a $500 \mathrm{~mL}$ plasma bottle with the anaerobic sludge, micronutrients and buffer solutions. The substrate to inoculum ratio was equal to $0.5 \mathrm{gCOD}$ (Chemical Oxygen Demand) of substrate (sludge or fatty residues) /g of organic matter $(\mathrm{OM})$ of anaerobic inoculum that concentration was equal to $4 \mathrm{~g}$ OM.L ${ }^{-1}$. Bottles were flushed by nitrogen gas, sealed and set on a mixing table $(100 \mathrm{rpm})$ in a thermostated room $\left(35^{\circ} \mathrm{C}\right)$. Biogas volume was measured by liquid displacement, the liquid being water at $\mathrm{pH}=2$ and $10 \mathrm{~g} \mathrm{~L}^{-1}$ of NaCl. Biogas composition was measured with a catharometer gas chromatograph Shimadzu GC 8A, equipped with an Alltech CTR1 column. BMP tests lasted up to 25 days. Every experiment was duplicated.

\subsection{Residues Pretreatments}

Pretreatments were carried out on a mixed waste composed of $66.6 \%$ of fatty wastewaters, $33.3 \%$ of waste activated sludge and $0.1 \%$ of fatty residues. They were performed at $80^{\circ} \mathrm{C}$ in a $2 \mathrm{~L}$ glass reactor equipped with a double jacket and a magnetic stirrer and at $120^{\circ} \mathrm{C}$ in a $900 \mathrm{~mL}$ reactor Zipperclave (Autoclave France) agitated and equipped with a ceramic oven. Potassium hydroxide was added in order to reach $\mathrm{pH}$ values equal to 8,9 or 10 after $30 \mathrm{~min}$ of treatments. Higher temperature $\left(120^{\circ} \mathrm{C}\right)$ treatments needed higher potassium hydroxide doses $\left(0.14,0.18\right.$ and $0.21 \mathrm{~g}_{\mathrm{KOH}}$ $\left.\mathrm{g}_{\mathrm{OM}}^{-1}\right)$ than the $80^{\circ} \mathrm{C}$ treatments $\left(0.12,0.14\right.$ and $0.18 \mathrm{~g}_{\mathrm{KOH}}$ $\left.\mathrm{g}_{\mathrm{OM}}{ }^{-1}\right)$.

\subsection{Analyses}

Dry matter (DM), organic matter (OM, corresponding to the part of DM which is volatile at $550^{\circ} \mathrm{C}$ ) and Chemical Oxygen Demand (COD) were determined according to Standard Methods [21].

Lipids concentration in residues was assessed by the amount of matter which was extracted by heptane (HEM, heptane extractable matter). This measure is usually performed with hexane but heptane was preferred because of its lower toxicity. A volume $\mathrm{V}$ of wastes sample was firstly acidified $(\mathrm{pH}<2)$ by sulfuric acid in order to maintain fatty acids in non ionic forms. A volume $\mathrm{V}$ of heptane and $\mathrm{V} / 2$ of methanol was added to the sample in an extraction funnel. Methanol was used to maintain lipoproteins in the aqueous phase. The funnel was set on an oscillating mixer (40 oscillations per minute) during $30 \mathrm{~min}$. The heptane phase was afterwards recovered and put into a flask. Heptane extraction was repeated until it remained colourless showing the sample exhausting. Heptane was removed by a roto-evaporator (rotavapor R, Büchi) at $80^{\circ} \mathrm{C}$ under partial vacuum. Extracted lipids were weighted after drying at $105^{\circ} \mathrm{C}$ during 24 hours.

\section{RESULTS AND DISCUSSION}

\subsection{Codigestion of Waste Activated Sludge and Fatty Residues}

The volume of methane which was produced during batch anaerobic digestion of waste activated sludge (WAS), fatty wastewaters (FW), fatty residues (FR), a mixture of WAS and FR (90/10) and a mixture of FW, WAS and FR 


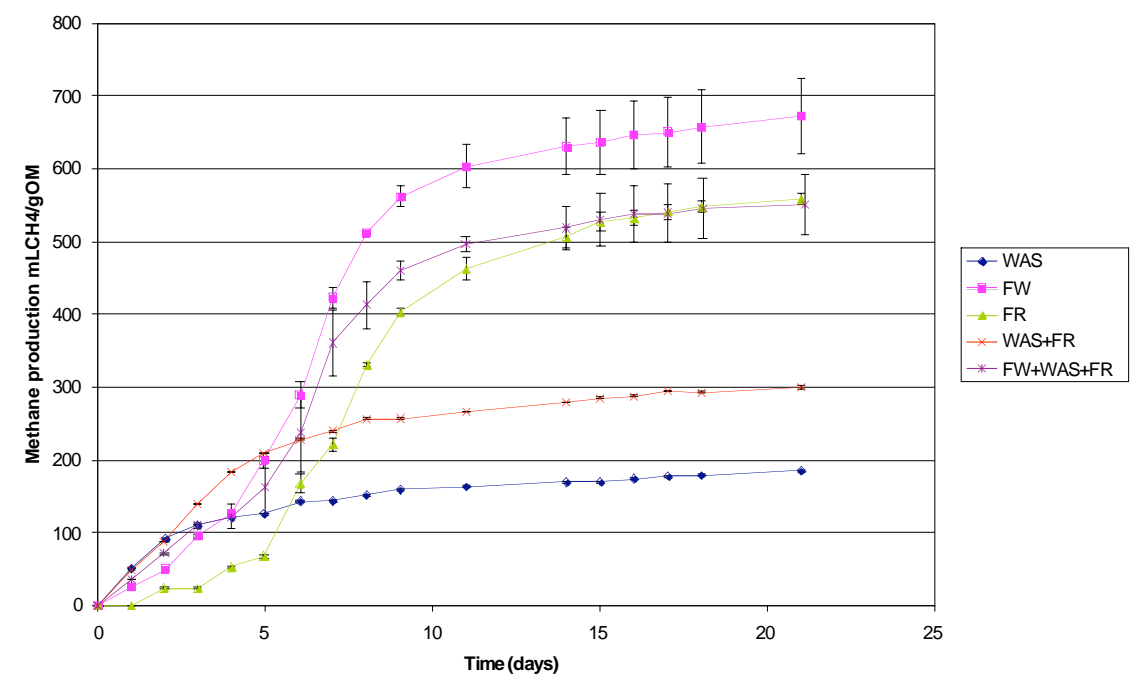

Fig. (1). Methane production during batch anaerobic digestion of waste activated sludge, fatty wastewaters, fatty residues alone and in mixture (mean of duplicates and standard deviation).

WAS: Waste Activated Sludge, FW : Fatty Wastewaters, FR : Fatty residues.

Table 2. Biomethane Potentials in $\mathrm{mL} \mathrm{CH}_{4} \cdot \mathrm{g}^{-1} \mathrm{OM}$ (Volume of Methane Produced per Gram of Organic Matter of Waste Introduced in Each Batch)

\begin{tabular}{|c|c|c|c|c|c|}
\hline \multicolumn{5}{|c|}{$1^{\text {st }}$ Series of Experiments } \\
\hline \hline WAS & FR & FW & $\begin{array}{c}\text { WAS/FR } \\
90 / 10\end{array}$ & $\begin{array}{c}\text { FW/WAS/FR } \\
66.6 / 33.3 / 0.1\end{array}$ \\
\hline $187 \pm 5$ & $565 \pm 8$ & $709 \pm 52$ & $301 \pm 2$ & $521 \pm 41$ & \multicolumn{2}{|c|}{ WAS/FW/FR } \\
\hline \multicolumn{7}{|c|}{$\mathbf{2}^{\text {nd }}$ Series of Experiments } \\
\hline WAS & WAS/FW/FR & WAS/FW/FR & WAS/FW/FR \\
& $80 / 19.9 / 0.1$ & $70 / 29.9 / 0.1$ & $60 / 39.9 / 0.1$ & $33.3 / 66.6 / 0.1$ & $608 \pm 24$ \\
\hline
\end{tabular}

WAS: Waste Activated Sludge, FW : Fatty Wastewaters, FR : Fatty residues.

$(66.6 / 33.3 / 0.1)$ is shown in Fig. (1). It has to be noted that the low concentration of FR $(0.1 \%)$ in the mixture was due to their low available quantities in wastewater treatment plants. Within the two first days of experiment, the highest volume of methane was produced by WAS and the mixture containing $90 \%$ of WAS. However these two substrates led to the lowest final methane volume. This means that fatty wastewaters and above all fatty residues needed a latency or adaptation phase of the anaerobic inoculum. Indeed, methane production from fatty residues actually started at 5 days. After 15-20 days a plateau was reached showing that anaerobic digestion was almost finished and the methane potential of each waste could be calculated (Table 2 ).

The values of methane potential (Table 2) show that waste activated sludge were hardly biodegradable with a biomethane potential around $190 \mathrm{~mL} \mathrm{CH} 4 \cdot \mathrm{g}^{-1} \mathrm{OM}$. This low value can be explained by the long residence time of the sludge in the aerated tank. On the other hand, fatty wastewaters from restaurants and fatty residues from wastewater treatment plants presented high methane potentials around 700 and $570 \mathrm{~mL} \mathrm{CH}_{4} \cdot \mathrm{g}^{-1} \mathrm{OM}$ respectively.
Fig. (2) shows the methane potential of three-wastemixtures with $0.1 \%$ of fatty residues as a function of fatty wastewater content. A very good fit was obtained by a linear correlation. The point which corresponded to WAS $(192 \mathrm{~mL}$ $\mathrm{CH}_{4} \cdot \mathrm{g}^{-1} \mathrm{OM}$ ) was on the regression line. This shows that conversion of sludge into methane was not improved by the presence of fatty wastewaters. On the other hand, the extrapolation of correlation line for $100 \%$ of FW led to a methane potential of $800 \mathrm{~mL} \mathrm{CH}_{4} \cdot \mathrm{g}^{-1} \mathrm{OM}$, which was higher than the experimental value $\left(650 \mathrm{~mL} \mathrm{CH} 4 \cdot \mathrm{g}^{-1} \mathrm{OM}\right)$. This shows that methane production by fatty wastewaters was enhanced thanks to the presence of sludge which may facilitate the contact between fatty molecules and anaerobic microorganisms.

\subsection{Saponification/Alkaline Pretreatment}

Potassium hydroxide was used rather than sodium hydroxide because toxicity of potassium towards anaerobic ecosystem was shown to be lower than sodium toxicity. Indeed, Mouneimne et al. [15] worked on the conversion of solid fatty residues collected from a wastewater treatment 


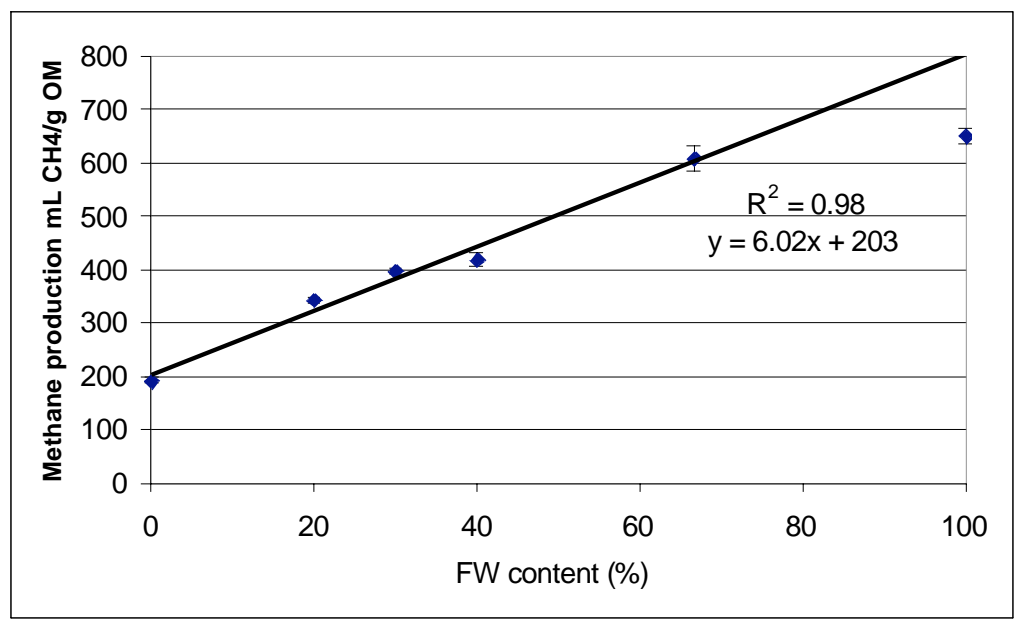

Fig. (2). Methane production during batch anaerobic digestion of mixtures of wastes as a function of fatty wastewaters content.

Table 3. Biomethane Potentials in $\mathrm{mL} \mathrm{CH}_{4} \cdot \mathrm{g}^{-1} \mathrm{OM}$ of the Mixed Waste FW/WAS/FR (66.6/33.3/0.1) with and Without Alkaline Pretreatment

\begin{tabular}{|c|c|c|c|c|}
\hline FW/WAS/FR $(\mathbf{6 6 . 6 / 3 3 . 3 / 0 . 1})$ & No Treatment & $\mathbf{p H = 8}$ & $\mathbf{p H = 9}$ & $\mathbf{p H = 1 0}$ \\
\hline \hline no treatment & $542 \pm 20$ & & & $573 \pm 13$ \\
\hline $80^{\circ} \mathrm{C}$ & & $576 \pm 4$ & $577 \pm 7$ & $582 \pm 13$ \\
\hline $120^{\circ} \mathrm{C}$ & & $565 \pm 7$ & & \\
\hline
\end{tabular}

Table 4. Percentage of Total Methane Produced Within the First 5 Days

\begin{tabular}{|c|c|c|c|c|}
\hline FW/WAS/FR $(\mathbf{6 6 . 6 / 3 3 . 3 / 0 . 1})$ & No Treatment & $\mathbf{p H = 8}$ & $\mathbf{p H = 9}$ & $\mathbf{p H = 1 0}$ \\
\hline \hline no treatment & $24 \%$ & & $38 \%$ & $35 \%$ \\
\hline $80^{\circ} \mathrm{C}$ & & $35 \%$ & $32 \%$ & $32 \%$ \\
\hline $120^{\circ} \mathrm{C}$ & & $39 \%$ & $32 \%$ \\
\hline
\end{tabular}

plant into volatile fatty acids. Saponification of residues by potassium hydroxide led to higher conversion yields than saponification by sodium hydroxide. Moreover, a concentration of $0.52 \mathrm{~mol} \mathrm{Na} \mathrm{L} \mathrm{m}^{-1}\left(12 \mathrm{gNa} \mathrm{L}^{-1}\right)$ and $0.74 \mathrm{~mol} \mathrm{~K} \mathrm{~L} \mathrm{~K}^{-1}$ $\left(28.8 \mathrm{gK} \mathrm{L}^{-1}\right)$ decreased batch methane production from acetate by $50 \%$. Finally, the potassium salts of straight chain fatty acids are the most soluble salts, compared to analogous sodium or calcium salts [14].

The methane potential of the three-wastes-mixtures with and without saponification/alkaline pretreatments are shown in Table 3. The impact of these pretreatments on methane production was relatively low $(+6-7 \%)$ and did not depend on $\mathrm{pH}$ nor temperature of treatment for $\mathrm{pH}$ ranging from 8 to 10 (addition of 0.12 to $0.21 \mathrm{~g}_{\mathrm{KOH}} \mathrm{g}_{\mathrm{OM}}{ }^{-1}$ ) and temperature ranging from 80 to $120{ }^{\circ} \mathrm{C}$. The low impact of saponification/alkaline pretreatments on the batch methane production of the mixed waste has to be compared to previous results obtained either on sludge or on fatty residues. First concerning fatty residues which represent $74.5 \%$ of $\mathrm{OM}$ and $83 \%$ of COD of the three-wastes-mixture, previous works showed no change in the methane potential of grease trap sludge from meat processing industry after treatment with $6-14 \% \mathrm{NaOH}$
( $\mathrm{pH} 12-12.2,[13])$. In the same way, saponification implied no change in the batch methane production from aeroflotation fat and a slight increase $(7 \%)$ of the methane potential of carcass fat [16]. Thermal alkali treatment was shown to be more efficient on waste activated sludge as a pretreatment at $130^{\circ} \mathrm{C}, \mathrm{pH}=10$ led to an increase of $30 \%$ of batch biogas production and $75 \%$ of biogas production in continuous digesters operated with a sludge retention time of 20 days [22]. However, sludge represented only $25.5 \%$ of OM and $17 \%$ of COD in the studied waste.

However, kinetics of batch anaerobic digestion were increased by these pretreatments as can be shown in Table 4 which displays the percentage of methane produced within the first 5 days of anaerobic digestion. This enhancement of anaerobic digestion kinetics is in agreement with previous results on fatty slaughterhouse wastes (aeroflotation fats and flesh fats from animal carcasses) indicating enhanced bioavailability by saponification of fatty wastes [16].

As higher temperature or higher potassium hydroxide doses did not lead to any significant improvement of anaerobic digestion performances, the least severe studied pretreatment conditions $\left(80^{\circ} \mathrm{C}\right.$ and $\mathrm{pH}=8,0.12 \mathrm{~g}_{\mathrm{KOH}} \mathrm{gOM}^{-1}$ corre- 
sponding to $3.5 \mathrm{~g}_{\mathrm{KOH}} \mathrm{L}^{-1}$ or $2.4 \mathrm{~g}_{\mathrm{K}} \mathrm{L}^{-1}$ ) may be proposed for a further investigation in continuous anaerobic reactors. Indeed, as batch experiments were carried out under conditions which are favourable to anaerobic digestion (low ratio substrate/inoculum), the interest of alkali pretreatment has to be confirmed on continuous anaerobic digesters because potential inhibitions of anaerobic digestion cannot been shown during batch runs. Nevertheless, most likely inhibition may be due to accumulation of long chain fatty acids [23, 24]. Indeed, Neves et al. [25] showed that high fat concentration (18 $\mathrm{g} \mathrm{COD} \mathrm{L}^{-1}$ reactor) in a mixture of cow manure and food wastes promoted a persistent inhibition of continuous anaerobic digestion although more oil was degraded in batch assays. Moreover, saponification/alkali treatment should enhance contact between anaerobic microorganisms and lipids. Finally, concentration of potasssium in the pretreated waste $\left(2.4 \mathrm{~g}_{\mathrm{K}} \mathrm{L}^{-1}\right)$ is lower than the inhibiting one $\left(28.8 \mathrm{~g}_{\mathrm{K}} \mathrm{L}^{-1}\right)$ [15].

\section{CONCLUSION}

Batch anaerobic digestion assays showed low methane potential of waste activated sludge originating from an extended aeration process (around $190 \mathrm{~mL} \mathrm{CH}_{4} \cdot \mathrm{g}^{-1} \mathrm{OM}$ ). Batch co-digestion with high methane potential wastes (fatty residues produced during pretreatments of the effluents from wastewater treatment plants : $560 \mathrm{~mL} \mathrm{CH} \mathrm{CH}^{-1} \mathrm{OM}$ and fatty wastewaters collected from restaurants: around $700 \mathrm{~mL}$ $\mathrm{CH}_{4} \cdot \mathrm{g}^{-1} \mathrm{OM}$ ) was successful even at high fat contents. But conversion of sludge into methane was not improved by the presence of fatty wastewaters. On the other hand, methane production by fatty wastewaters was enhanced thanks to the presence of sludge which may facilitate the contact between fatty molecules and anaerobic microorganisms.

Saponification/alkali pretreatments allowed to improve kinetics of anaerobic digestion but had a low impact on methane potential $(+6-7 \%)$ of the mixed waste composed of $66.6 \%$ of fatty wastewaters, $33.3 \%$ of waste activated sludge and $0.1 \%$ of fatty residues. As results did not depend on $\mathrm{pH}$ ranging from 8 to 10 (addition of 0.12 to $0.21 \mathrm{~g}_{\mathrm{KOH}} \mathrm{g}_{\mathrm{OM}}{ }^{-1}$ ) nor temperature ranging from 80 to $120{ }^{\circ} \mathrm{C}$, the least severe studied pretreatment conditions $\left(80^{\circ} \mathrm{C}\right.$ and $\left.\mathrm{pH}=8\right)$ will be further applied on continuous anaerobic reactors to simulate full scale plant and assess inhibition phenomena by long chain fatty acids.

\section{ACKNOWLEDGEMENT}

The authors are grateful to l'Agence de l'eau Artois Picardie for financial support.

\section{REFERENCES}

[1] Y.H. Ahn, "Sustainable nitrogen elimination biotechnologies: A review," Process Biochemistry, vol. 41, pp. 1709-1721, 2006.

[2] T. Khin and A.P. Annachhatre, "Novel microbial nitrogen removal processes", Biotechnology Advances, vol. 22, pp. 519-532, 2004.

[3] U. Kepp and O. E. Solheim, "Thermo dynamical assessment of the digestion process", in CIWEM/Aqua Enviro 5th European Biosolids and Organic Residiuals Conference, Cedar Court, Wakefield, UK, 2000, avaible at http://www.cambi.no/photoalbum/ view2/P3NpemU9b3JnJmlkPTIyMDAxOCZ0eXB1PTE [accessed 28/04/2010]

[4] H. Carrere, C. Bougrier, D. Castets and J.P Delgenès., "Impact of initial biodegradability on sludge anaerobic digestion enhancement by thermal pretreatment." Journal of Environmental Science and Health Part a, vol. 43, pp. 1551-1555, 2008.
[5] M. Weemaes and W. Verstraete, "Evaluation of current wet sludge disintegration techniques." Journal Chemistry Technology Biotechnology, vol. 73, pp. 83-92, 1998.

[6] A. Elliott and T. Mahmood, "Pretreatment technologies for advancing anaerobic digestion of pulp and paper biotreatment residues." Water Research, vol. 41, pp. 4273-4286, 2007.

[7] L. Appels, J. Baeyens, J.Degreve and R. Dewil, "Principles and potential of the anaerobic digestion of waste-activated sludge." Progress in Energy and Combustion Science, vol. 34, pp. 755-781, 2008.

[8] J. Chauzy, D. Cretenot, A. Bausseon and S. Deleris, "Anaerobic digestion enhanced by thermal hydrolysis: First reference BIOTHELYS $^{\circledast}$ at Saumur, France", in Facing sludge diversities: challenges, risks and opportunities, Turkey: Antalya, 2007, pp. 141148.

[9] U. Kepp, I. Machenbach, N. Weisz, and O.E. Solheim, "Enhanced stabilisation of sewage sludge through thermal hydrolysis - three years of experience with full scale plant". Water Science and Technology, vol. 42(9), pp. 89-96, 2000.

[10] U. Neis, K. Nickel and A. Lunden, "Improving anaerobic and aerobic degradation by ultrasonic disintegration of biomass", in Facing Sludge Diversities: Challenges, Risks and Opportunities, Turkey: Antalya, 2007, pp. 125-132.

[11] S. Luostarinen, S. Luste, and M. Sillanpää. "Anaerobic codigestion of sewage sludge and grease trap sludge", in Anaerobic Digestion of Solid Waste \& Energy Crops. Tunisie: Hammamet, 2008.

[12] J.C. Kabouris, U. Tezel, S.G. Pavlostathis, M. Engelmann, J. Dulaney, R.A. Gillette and A.C. Todd, "Methane recovery from the anaerobic codigestion of municipal sludge and FOG", Bioresource Technology, vol. 100, pp. 3701-3705, 2009.

[13] S. Luste, S. Luostarinen and M. Sillanpää, "Effect of pre-treatments on hydrolysis of grease trap sludge from Meat-processing industry"., in Anaerobic Digestion of Solid Waste \& Energy Crops, Tunisie: Hammamet, 2008.

[14] X. Lefebvre, E. Paul, M. Mauret, P. Baptiste, and B. Capdeville, "Kinetic characterization of saponified domestic lipid residues aerobic biodegradation". Water Research, vol. 32, pp. 3031-3038, 1998.

[15] A. H. Mouneimne, H. Carrere, N. Bernet and J.P. Delgenes, "Effect of saponification on the anaerobic digestion of solid fatty residues", Bioresource Technology, vol. 90, pp. 89-94, 2003.

[16] A. Battimelli, H. Carrère and J.P. Delgenès, "Saponification of fatty slaughterhouse wastes for enhancing anerobic biodegradability", Bioresource. Technology, vol. 100, pp. 3695-3700, 2009.

[17] J. Canler, "Performances des systèmes de traitement biologique aérobie des graisses - Graisses issues des dégraisseurs de station d'épuration traitant des effluents à dominances domestique", In: Document technique FNDAE, Cemagref éd., France, 2001.

[18] L. Masse, K.J. Kennedy and S. Chou, "Testing of alkaline and enzymatic hydrolysis pretreatments for fat particles in slaughterhouse wastewater". Bioressource Technology, vol. 77, pp.145-155, 2001.

[19] C. Bougrier, J.P. Delgenès and H. Carrère, "Effects of thermal treatments on five different waste activated sludge samples solubilisation, physical properties and anaerobic digestion", Chemical Engineering Journal, vol. 139, pp.236-244, 2008.

[20] M.J. Cuetos, X. Gomez, M. Otero and A. Moran, "Anaerobic digestion and co-digestion of slaughterhouse waste (SHW): Influence of heat and pressure pre-treatment in biogas yield", in WasteEng08, Second International Conference of Engineering for Waste Valorisation, Patras, Greece, 2008.

[21] APHA, American Public Health Association, American Water Works Association, Water Pollution Control Federation. L.S. Clesceri, A. E. Greenberg, and R.R. Trussel, Eds. Standard Methods for the Examination of Water and Wastewater, $18^{\text {th }}$ ed., Washington 1992.

[22] A. Valo, H. Carrère and J.P. Delgenès, "Thermal, chemical and thermo-chemical pre-treatment of waste activated sludge for anaerobic digestion", Journal of Chemical Technology and Biotechnology, vol. 79, pp. 1197-1203, 2004.

[23] E. Salminen and J. Rintala, "Anaerobic digestion of organic solid poultry slaughterhouse waste - a review". Bioresource Technology, vol. 83, pp. 13-26, 2002. 
[24] O. Stabnikova, S.S. Ang, X.Y. Liu, V. Ivanov, J.H. Tay and J.Y. Wang, "The use of hybrid anaerobic solid-liquid (HASL) system for the treatment of lipid-containing food waste". Journal of
Chemical Technology and Biotechnology, vol. 80, pp. 455-461, 2005.

[25] L. Neves, R. Oliveira and M.M. Alves, "Co-digestion of cow manure, food waste and intermittent input of fat." Bioresource Technology, vol. 100, pp.1957-1962, 2009. (http://creativecommons.org/licenses/by-nc/3.0/g) which permits unrestricted, non-commercial use, distribution and reproduction in any medium, provided the work is properly cited. 